Research Article

\title{
Real Optimisation of a PV System Based on Hysteresis Controllers over Sun: Design, Implementation, and Comparative Study
}

\author{
Houda Brahmi $\mathbb{D}^{1},{ }^{1}$ Rabiaa Gammoudi $\mathbb{D}^{2}$, and Rachid Dhifaoui $^{3}$ \\ ${ }^{1}$ University of Tunis el Manar, Higher Institute of Medicals Technologies of Tunis (ISTMT), Unit of Research ERCO-INSAT, \\ 9 Rue Zouhair Essafi, 1006 Tunis, Tunisia \\ ${ }^{2}$ National High School of Engineering of Tunis (ENSIT), Unit of Research ERCO-INSAT, Avenue Taha Hussein Montfleury, \\ 1008 Tunis, Tunisia \\ ${ }^{3}$ University of Carthage, National Institute of Applied Sciences and Technologies, Unit of Research ERCO-INSAT, \\ Centre Urbain Nord BP 676, 1080 Tunis, Tunisia
}

Correspondence should be addressed to Houda Brahmi; houda.brahmi@istmt.utm.tn

Received 7 December 2020; Revised 12 February 2021; Accepted 9 April 2021; Published 24 April 2021

Academic Editor: João M. Tavares

Copyright $(92021$ Houda Brahmi et al. This is an open access article distributed under the Creative Commons Attribution License, which permits unrestricted use, distribution, and reproduction in any medium, provided the original work is properly cited.

This paper presents two strategies for controlling photovoltaic power based on hysteresis controllers. These regulators adjust the photovoltaic current and voltage in order to supply the load with maximum power. The regulators are designed, produced, and tested within the ERCO-INSAT research unit. The proposed structures are experienced, and the results prove the robustness of the controls and confirm their abilities to maintain op timal power in real time. We also presented the mathematical model of the photovoltaic system, a dynamic model taking into account the variation of the climatic parameters as well as the internal parameters of the models such as the series and shunt resistances. Simulation results are validated by an experimental test that confirms the effectiveness of the current and voltage controllers carried out. This simulation is already based on the use of real solar radiation and temperature scenarios recorded by a digital oscilloscope via the intermediary of the sensors. The two techniques are ensured by the use of the Dspace card to control the DC/DC converter and to implement the chosen controls.

\section{Introduction}

Following the report published by the International Energy Agency in 2018, the global energy consumption and demand in 2030 will grow by $45 \%$. This increase is due to the demographic development and especially the industrialization in the countries which have a number of inhabitants exceeding the two billion (China, India, etc. ) [1-4].

On one hand, conventional nonrenewable resources, such as coal, oil, natural gas, and uranium, occupy almost the majority of world production of electric energy. This domination in production can cause a risk of exhaustion of resources called "fossil."

On the other hand, an environmental problem arises since this type of energy resource causes much damage to the environment such as emissions of greenhouse gases that cause the increase in pollution and global warming. Therefore, to make the supply of electricity more environmentally friendly, the exploitation of new sources of energy production called "renewable energy" is essential [5-10].

One of these nonpolluting energies is photovoltaic energy. This nonexhaustible source, respecting the environment, makes it possible to produce energy through a direct transformation of solar radiation into electrical energy. This conversion is achieved through the use of solar cells also called "photovoltaic" (PV) and is mainly based on a physical phenomenon "photovoltaic effect."

The commercialization of photovoltaic energy can be in the form of panels or in the form of PV generators. 
The photovoltaic panels are characterized by the nonlinearity of their output characteristics which are influenced by environmental factors (temperature and illumination). To take advantage of the reliable use of this source, it is necessary to reach and use adequately the maximum of its energy [11-15].

Powering a system from a photovoltaic source is among the most widely used applications and is the subject of several research works [16]. From a practical standpoint, these applications are difficult to implement.

To ensure a continuous optimal operation, an adaptation between the photovoltaic source and the load is necessary. This adaptation is performed by the insertion of a static DC/DC converter which must be controlled by an optimum operating point tracking system. Different methods of maximum power extraction are proposed by the literature [17-19].

In January 1968, A. F. Boehringer developed the first MPPT control law suitable for a photovoltaic energy source. This control is based on an adaptive control algorithm that keeps the system running at its maximum power point. The principle of this command is still valid, and it is now applied to other more efficient digital algorithms with an improvement in the response time and the search precision of the PPM [20].

The other maximum power extraction methods are classified into three main families; the first is the family of methods based on proportionality relations which are also called "indirect or static methods." The results developed in [21] show the very great importance dedicated to climatic factors which make it possible to determine the maximum power point. These methods are generally relative to a welldefined installation. We find the control in voltage regulation and the control in regulation current.

The methods of the second family are called "high performance algorithm commands" or "direct or dynamic methods."

They use measurements of the voltage and current values of the PV panels used. Among these methods, we find the "Perturb and Observ" (P\&O) method and the "incremental conductance" method. The research developed in [22-31] shows that these algorithms are essentially based on the variation of these measurements (current, voltage).

There is also the family of variable structure methods. The developments presented in $[32,33]$ show the principle of the methods. The principle of this approach consists essentially in forcing the system to reach a given surface called "sliding surface" and to stay there until reaching equilibrium.

There is also the family of intelligent methods such as "'the genetic algorithm, neural network, and fuzzy logic" The advantage of techniques based on fuzzy logic is that they can work with imprecise input values and they do not need a high precision mathematical model. In addition, they can deal with nonlinearities [34,35].

In recent years, the use of control by neural networks, in various fields of application, does not cease increasing because it operates from a black box which does not require detailed information on the functioning of the system [36-39].
Genetic algorithms are very relevant for global structural optimization problems (problems with several constraints). As they allow great freedom in the configuration and implementation of the various processing operations [40].

The work developed and presented in this article is based essentially on the establishment of a test bench for the extraction of maximum photovoltaic power. It is recommended that the bench is as complete as possible in terms of equipment and logistics control and optimization to ensure a core of research and development to enhance this type of application.

The main objective of the study carried out in this work is to analyze the principle of maximum power operation based on two real hysteresis controllers and to present the prototypes of these regulators.

The hysteresis regulator is commonly used in industry thanks to its sensitivity to follow references with precision. This effectiveness is proven especially on a practical level.

The different works [41-43] show that this technique is based on controlling the converter so that the variations in current or voltage are limited in a band surrounding the references. Depending on the operating conditions, the switching frequency of the switches follows a random variation.

Subsequently, we will proceed to the implementation of these controls techniques whose test bench consists essentially of a photovoltaic generator installed on the roof of the research unit with a maximum power of $500 \mathrm{~W}$, a DCDC converter (buck, push-pull), and a resistive load. The command part is ensured by a PC integrating a DS1104 dSpace card. The experimental part is accompanied by a simulation based mainly on the use of the two real and random scenarios of solar radiation and temperature. These scenarios are recorded via a digital oscilloscope (METRIXOX 7104). Solar radiation and temperature are measured, first, by two sensors which are designed and produced by our research team. The experimental results presented in this work are recorded for a period of 15 minutes, which allows us to properly test the effectiveness of these two regulators.

\section{Problem Identification}

In the case where the PVG is directly coupled to the load, the operating point is the intersection between the electrical characteristic of the PVG and the load [17]. The corresponding power at this operating point is not necessarily equal to the maximum power available from the PV array (Figure 1).

In order to reach the maximum power point which corresponds to the optimum power generated by the PV generator, an adaptation stage must be inserted and provided with a control to ensure the follow-up of the MPP while acting in an automatic way on the duty cycle of the selected static converter.

These commands are generally referred to in the literature as "Maximum Power Point Tracking" (MPPT). These techniques essentially consist in bringing each time the operating point of the photovoltaic generator to the MPP 


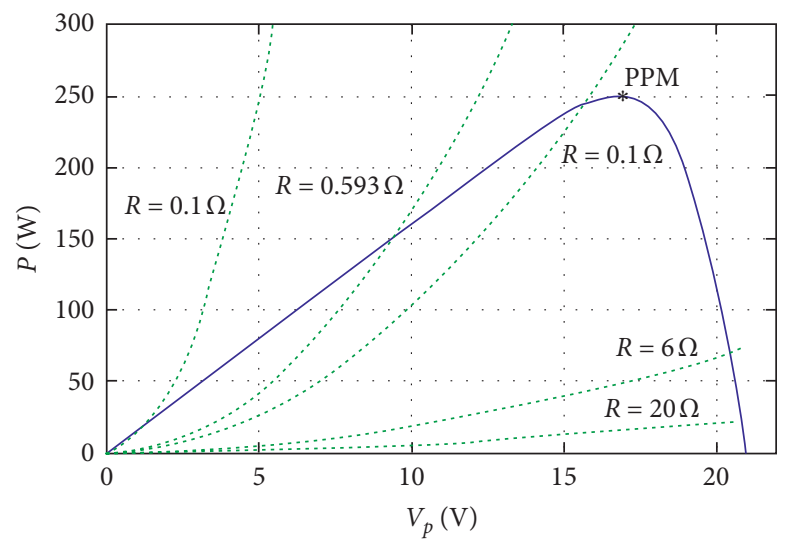

FIgURE 1: Evolution of the operating point with a direct link between the source and the load.

whatever the abrupt variations are in the load or the weather conditions.

As a recap of the different problems of a PV system, we have the following:

(i) The strong dependence of the characteristics of a photovoltaic generator on climatic conditions.

(ii) The adaptation of the impedances between the source and the load in order to obtain an optimal operation.

(iii) The limits of use and the divergences of several algorithms for extracting maximum power.

(iv) The need for experimental validation in order to prove the effectiveness of an approach compared to others.

(v) Check and control the adapter device from current and voltage.

\section{Solar PV System Configuration}

The major drawback of the direct connection between the source and the load is the link between the power extracted from the source and an application that is often very far from the maximum power that can deliver the photovoltaic generator.

So, the insertion of a static converter, continuous/continuous type, is necessary. This converter acts as an adapter between the source and the load. In order to reach the operating point which corresponds to the optimum power generated by the PV generator, the adaptation stage must be provided with a command to track the MPP while acting automatically on the duty cycle of the chosen static converter.

These commands are generally named "Maximum Power Point Tracking" (MPPT). These techniques essentially consist in bringing each time the operating point of the photovoltaic generator to the MPP, whatever the sudden variations are in the load or the weather conditions [44-48].

The principle of the proposed and implemented control solutions is given in Figure 2. The structure is based on a push-pull converter and a buck converter.

The interest in using this type of converter (push-pull) in this configuration is the increase of the GPV voltage. This converter operates with a gain of 20 . So, we have an output voltage of the push-pull stage which is $20 \times V_{p v}$. Finally, the control is ensured through a buck converter and we have $V_{c h}=m \times \alpha \times V_{p v}$.

The push-pull converter and the buck converter used in this system have the function of transforming the fixed resistor $R$ into an equivalent variable one. In other words, the equivalent resistor $R_{\beta}=f(\alpha) \times R$ connected to the photovoltaic generator becomes a function value of the control variable $\alpha$.

3.1. Modelling and Characterization of PVGenerator. A solar cell is basically a diode having a $\mathrm{p}-\mathrm{n}$ junction exposed to light. When the diode is sufficiently illuminated by sunlight, it generates an electric current in a load resistor. The principle of converting solar radiation into electrical energy is based on the "photovoltaic effect" [49-51]. The energy extracted from the photovoltaic system is one of the reliable natural energy sources because of its ecological nature.

The electrical behaviour of photovoltaic cells is nonlinear; several works have approached this theme of modelling. We use in this work the model described by system (1) and (2). Figure 3 shows the electrical circuit on which our model is based.

The main purpose of this model is to estimate the operating point of the PV generator from three climate variables: solar radiation, temperature, and wind speed. This model integrates also the dynamic variation of series and shunt resistances: 


$$
\begin{aligned}
& \left\{\begin{array}{l}
f_{W}\left(\vartheta_{W}\right)=\exp \left(-\gamma\left(\vartheta_{W}-1\right)\right) \quad \vartheta_{W} \geq 1, \\
T j=T_{A}+273.15+33.75 f_{W}\left(\vartheta_{W}\right) E_{s}, \\
V_{T}=\frac{N_{s} n_{s} \mathscr{K}_{I} \mathscr{K}_{B}}{Q} T j, \\
I_{s}=I_{s r}\left(\frac{V_{T}}{V_{T r}}\right)^{3} \exp \left(\frac{W_{g}}{V_{T r}}-\frac{W_{g}}{V_{T}}\right), \\
I_{p h}=E_{s}\left[I_{p h r}+\mathscr{K}_{T}\left(V_{T}-V_{T r}\right)\right], \\
V_{o c}=V_{T} \log \left(1+\frac{I_{p h}}{I_{s}}\right), \\
I_{p}-N_{p} i_{p h}+N_{p} i_{s}\left(\exp \left(\frac{V_{p}+\left(N_{s} n_{s} r_{s} / N_{p}\right) I_{p}}{N_{s} n_{s} v_{T}}\right)-1\right)+\frac{1}{N_{s} n_{s} r_{s h}}\left(V_{p}+\frac{N_{s} n_{s} r_{s}}{N_{p}} I_{p}\right)=0 \\
R_{s h} \simeq \frac{V_{T}}{I_{s}} \exp \left(-\frac{V_{o c}}{V_{T}}\right), \\
\frac{R_{s} V_{T}}{I_{s}} \exp \left(-\frac{R_{s} I_{p h}}{V_{T}}\right)
\end{array}\right. \\
& \left\{\begin{array}{l}
W g=N_{s} n_{s} w_{g}, \\
V_{T r}=298.15\left(\frac{N_{s} n_{s} \mathscr{K}_{I} \mathscr{K}_{B}}{\mathscr{Q}}\right) \\
\mathscr{K}_{T}=\frac{N_{p} k_{T} Q}{N_{s} n_{s} \mathscr{K}_{I} \mathscr{K}_{B}} .
\end{array}\right.
\end{aligned}
$$

This model involves two parameters $I_{s r}$ and $I_{p h r}$ which correspond to the saturation current and photon current at the reference regime. The values of these quantities are evaluated respectively in open-circuit and short-circuit conditions.

The PV characteristics for the photovoltaic generator describe previously by system (1) and (2), are plotted in Figures 4 and 5 for various values of solar radiation and temperature.

3.1.1. Influence of Solar Radiation. To show the influence of solar irradiance on the overall behaviour of a PV panel, we set the value of the junction temperature at $25^{\circ} \mathrm{C}$. The curves of Figure 4 reflect sufficiently the functional behaviour of the photovoltaic generator.

So, we can note the following:

(i) The short-circuit current is very sensitive to solar irradiance. It increases proportionally with illumination, a condition imposed here by the mathematical model.

(ii) The optimum power has almost the same behaviour as the short-circuit current. The optimal trajectory is a curve of great positive slope according to the optimal tension.

3.1.2. Influence of Junction Temperature. The curves of Figure 5 are plotted at $1000 \mathrm{~W} / \mathrm{m}^{2}$ and four values of junction temperature. These curves also sufficiently reflect the reality of the functional behaviour of the photovoltaic panel vis-à-vis the change in temperature:

(i) The short-circuit current is almost insensitive to the change in temperature.

(ii) Optimal power decreases with increasing temperature. The optimal trajectory constitutes a positive slope curve as a function of the optimal tension. 


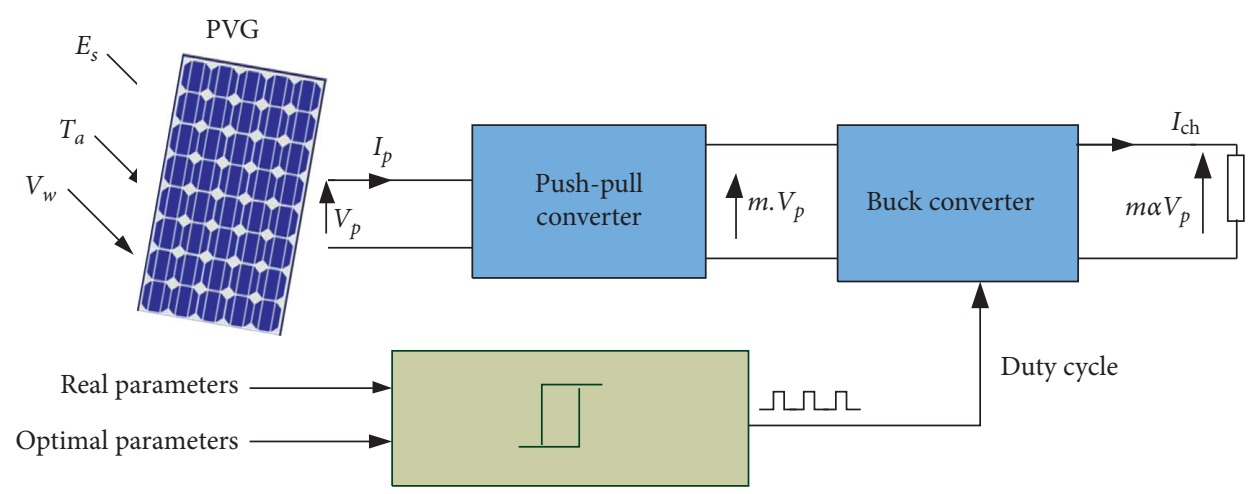

Figure 2: Structure of the study system.
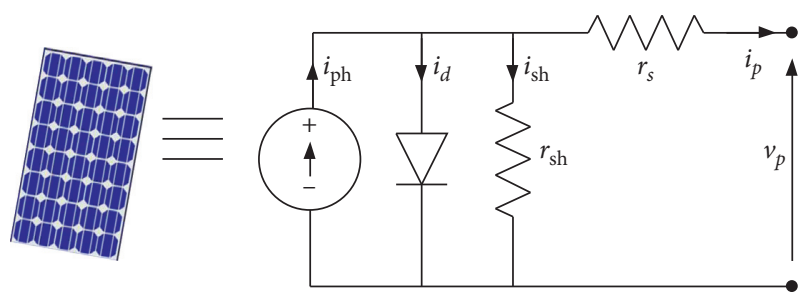

FIGURE 3: Electrical model of a solar cell.

\section{Controls Concepts}

The performance of the converter depends on the control strategy adopted to generate the control signal (PWM). Many digital and analogue methods are available to control the converters (such as dynamic methods and static methods). Hysteresis control techniques are the most popular because they offer good stability of current and voltage, a very fast response, and robust control and are not complicated to implement.

4.1. Hysteresis Current Controller Concept. The basic structure of this regulation mode is given in Figure 6:

Figure 7 describes the principle of the hysteresis regulator used as a current controller. When the photovoltaic current $I_{p v}$ deviates from the reference value of $(\Delta h / 2)$, fixed by the band control of the hysteresis controller, the output current error exceeds the upper hysteresis band $-(\Delta h / 2)$ and the switching signal $\mathrm{C}$ becomes low. In case the error is greater than $+(\Delta h / 2)$, the switching signal $\mathrm{C}$ becomes high. If the error is now between $-(\Delta h / 2)$ and $+(\Delta h / 2)$, the switching signal does not switch $[52,53]$.

Thus, the hysteresis controller generates a control signal $\mathrm{C}$ to control the converter switch in order to maintain the current error $\Delta i$ within its band. This logic signal is given by the following relation:

$$
\begin{cases}C=1, & \text { if } \Delta_{i} \geq+\frac{\Delta_{h}}{2}, \\ C=0, & \text { if } \Delta_{i} \leq-\frac{\Delta_{h}}{2} .\end{cases}
$$

4.1.1. Design of Hysteresis Current Regulator. Referring to the principle of the hysteresis control described above, the developed control circuit is based around many operational amplifiers including the comparator, the inverting, and the summing amplifier. At this level, it is important to note that even for resistances having the same characteristics, most often we measure a deviation of value because of the tolerance. So, we have inserted in the circuit of Figure 8 adjustable potentiometers in series with the resistors to compensate for this difference. On another aspect, to ensure the stability of the signals at the output of the AOPs, we attack these integrated circuits by their negative inputs, which is why we used a few unit gain amplifiers, although to reverse the input if necessary. To ensure the "galvanic" isolation of the masses between the control part and the power stage, the HCPL optcoupler 2531 based on a phototransistor is used. Figure 8 gives the detailed electronic diagram of the hysteresis current controller card where the IC1 circuit represents a unity gain inverting amplifier used to invert the reference signal of the current. A low amplitude signal oscillating around zero is added to the output of IC1 constituting the tolerance band, delivered by the circuit IC2. This addition is ensured by the summing circuit IC3 whose output is compared to the current in the load using the comparator IC4. Moreover, the result of the comparison, output of the circuit IC4, is an alternative signal oscillating between $-\mathrm{Vcc}$ and $+\mathrm{Vcc}$. At first, this signal is complemented by IC5. In a second time, it is added using the summing IC6 a continuous offset component equal to $-\mathrm{Vcc}$ to eliminate its negative component. Finally, to exploit this signal to the control of buck converter, we opted to isolate the masses by an optocoupler HCPL 2531 IC7.

Figure 9 gives an overview of the electronic card of the hysteresis current controller.

4.1.2. Simulation of $P V$ System with Hysteresis Current Control. The test system considered in this paper is a PV system connected to a resistor load. The system has a PV array, a push-pull converter, and the buck converter. The PV system is simulated, using the one diode model presented in Section 2. Each module consists of 36 photocells. 


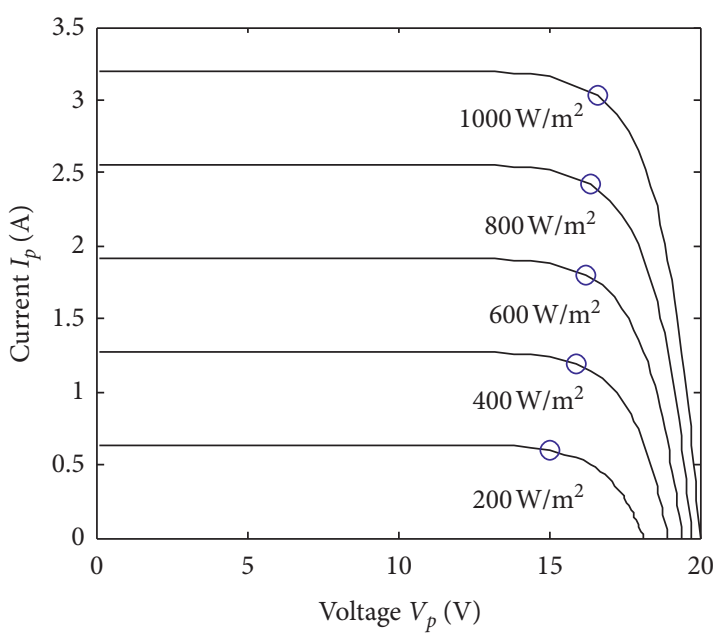

(a)

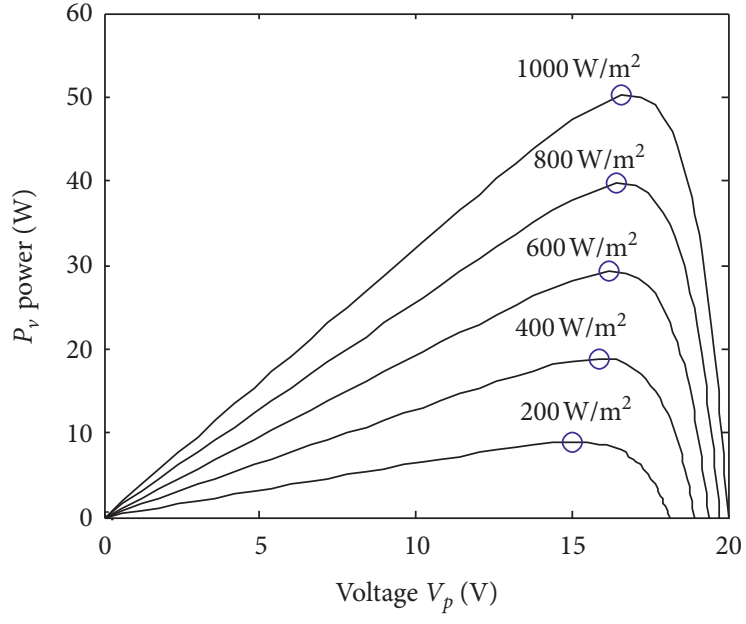

(b)

FIGURE 4: Output characteristics of a PV panel with solar radiation.

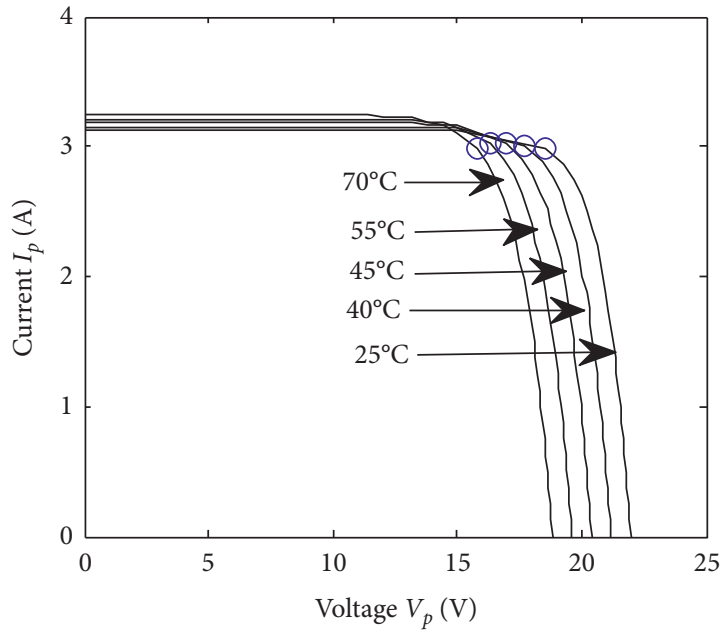

(a)

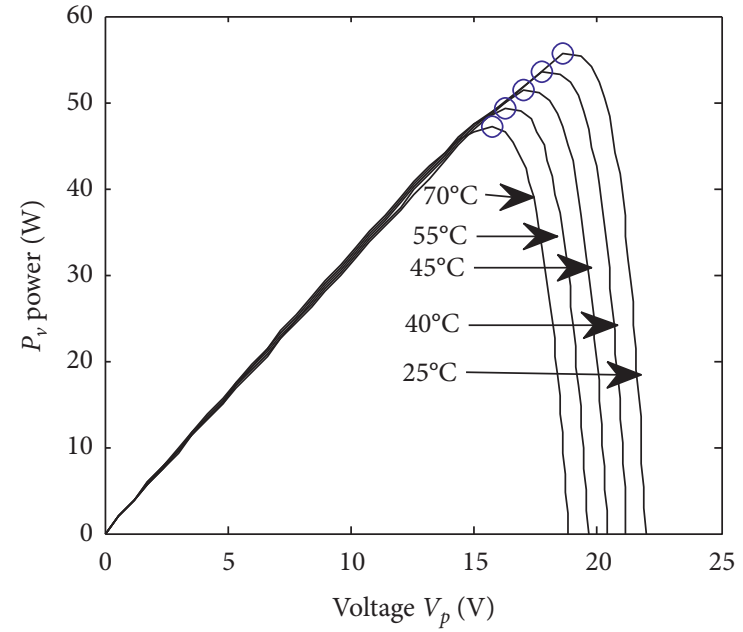

(b)

Figure 5: Output characteristics of a PV panel with junction temperature variation.

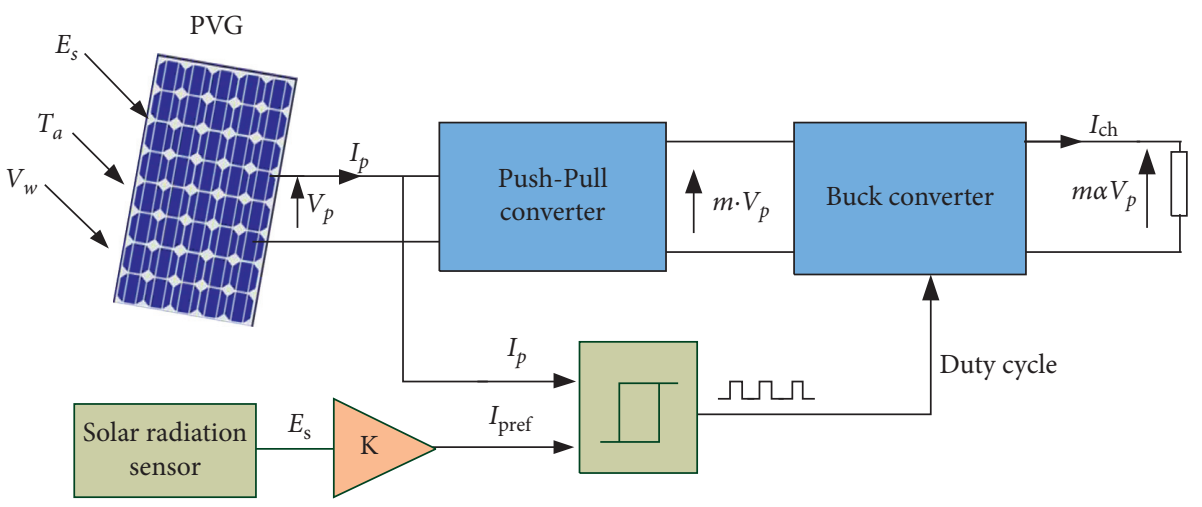

FIGURE 6: Structure of the hysteresis current controller system. 


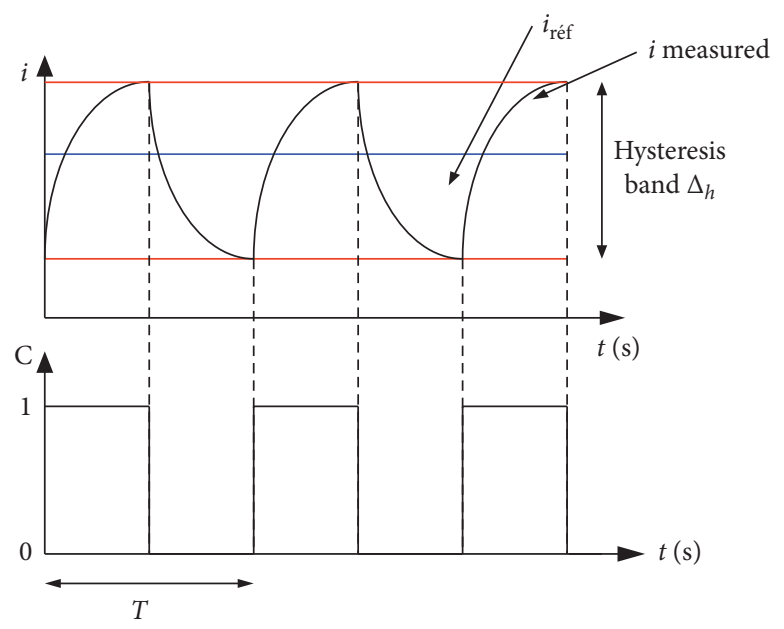

Figure 7: Principle of hysteresis regulator.

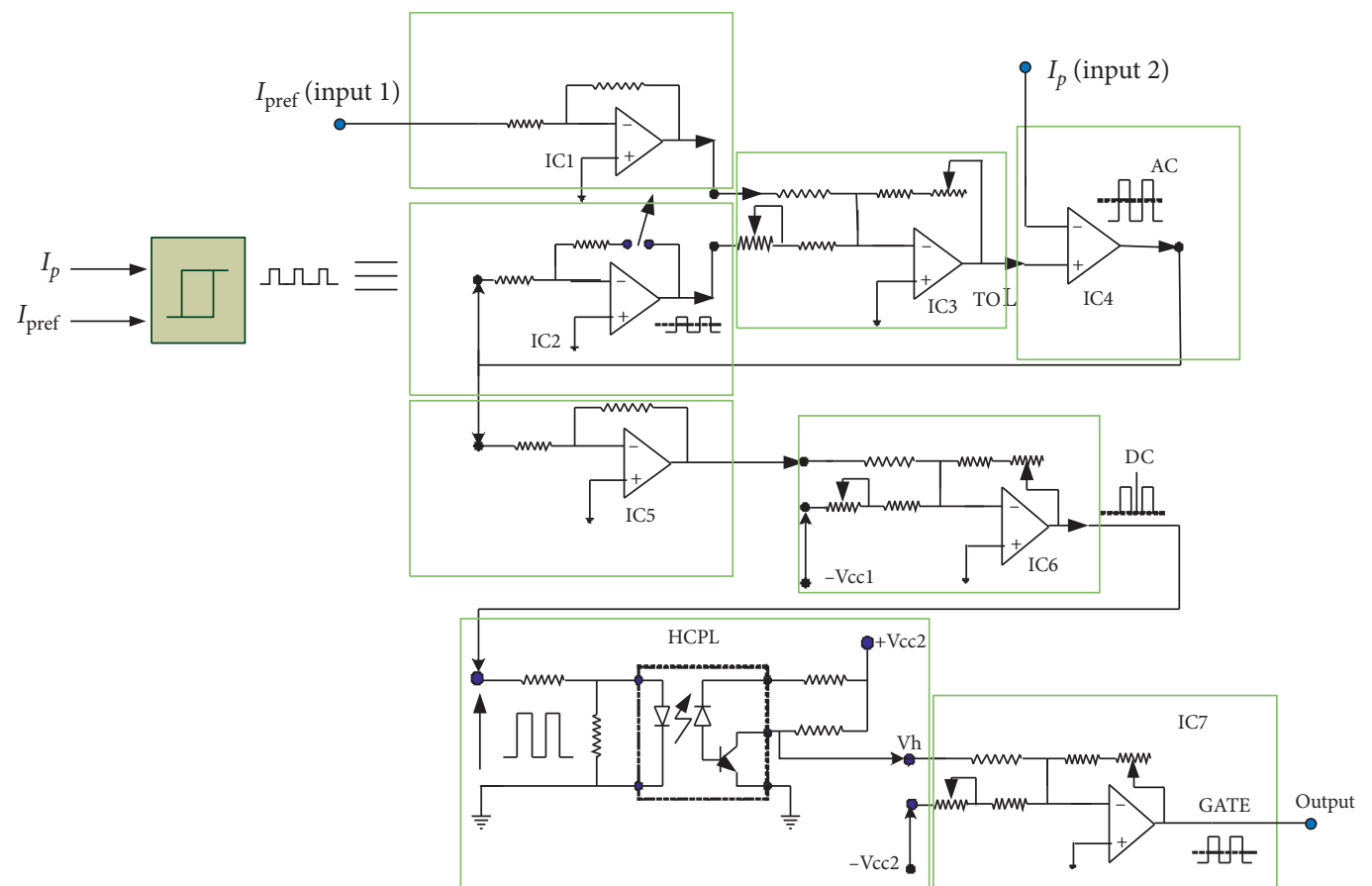

Figure 8: Design of a hysteresis current regulator.

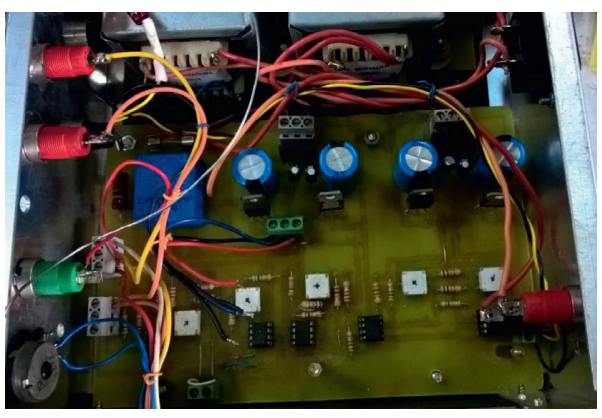

FIgURE 9: Overview of the card of hysteresis current controller.
To check the performance of the proposed regulator, a MATLAB/Simulink model of the PV system was initially developed. The parameters of the TITAN STP-12-50 type PV module are used for the PV generator model (the specifications are listed in Table 1).

In order to verify the robustness of the proposed approach, we have presented real scenarios where the solar radiation and temperature vary randomly. Figures 10 and 11 show the evolution of the real solar radiation and temperature.

Figure 12 presents the evolution of the actual and the optimal currents. These results show that the $I_{p v}$ current faithfully follows its reference which constitutes the objective of 
TABLE 1: Parameters of the PV generator used in simulation.

\begin{tabular}{lc}
\hline \multicolumn{2}{c}{ Solar panel TITAN-12-50 cell type: EFG multicristallin } \\
\hline Number of series cells $n s$ & 36 \\
Number of parallel PV arrays Np & 1 \\
Number of series PV arrays Ns & 10 \\
Open-circuit voltage in STC (per one PV array) & $21 \mathrm{~V}$ \\
Short-circuit current en STC (per one PV array) & $3.2 \mathrm{~A}$ \\
Optimal voltage in STC (per one PV array) & $17.2 \mathrm{~V}$ \\
Optimal current in STC (per one PV array) & $2.9 \mathrm{~A}$ \\
Optimal power in STC & $450 \mathrm{~W}$ \\
\hline
\end{tabular}

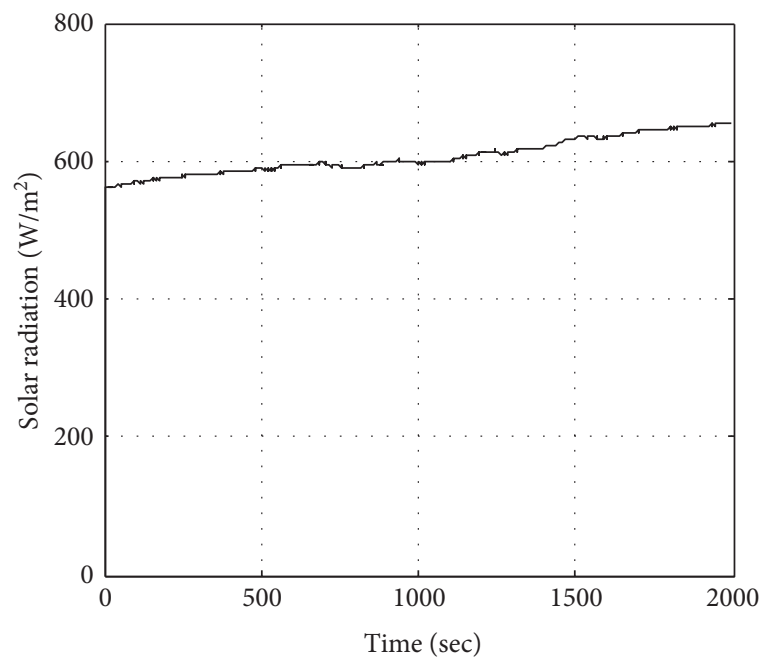

Figure 10: Evolution of solar radiation.

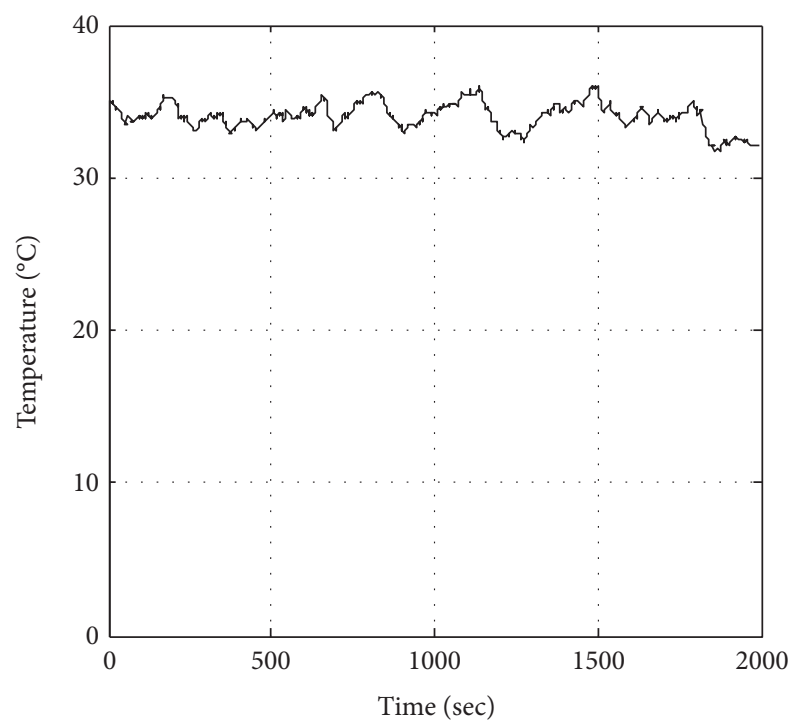

Figure 11: Evolution of temperature.

our control. So finally, we can confirm that the PV current converges towards its reference value, which is imposed by the solar radiation.

Figure 13 gives the exact movement of the two real and optimal powers of a PVG and a zoom of this movement. This figure allows us to conclude that our control responds appropriately, given the existence of a concordance between the two powers.

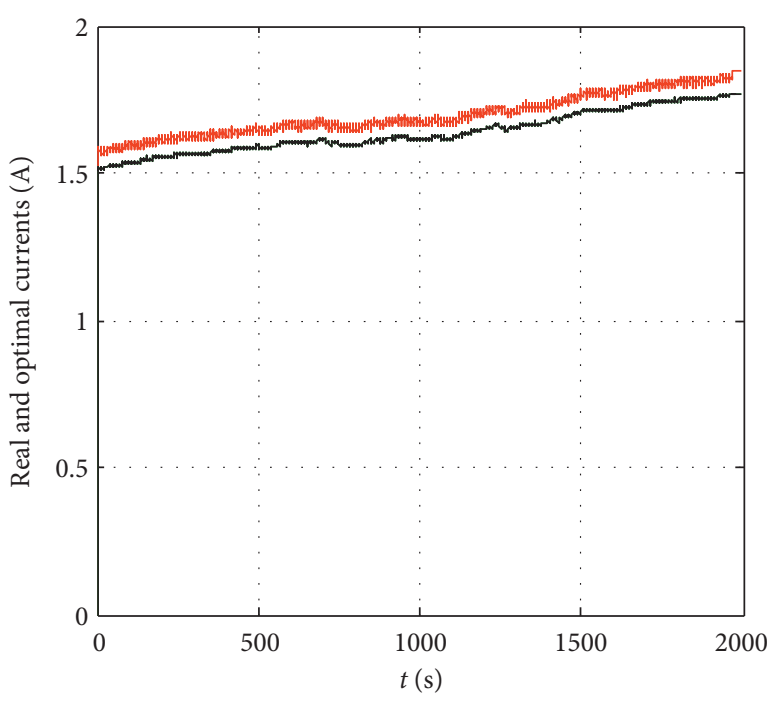

FIGURE 12: Evolution of $I_{p v}$ and $I_{p v_{-} o p t}$.

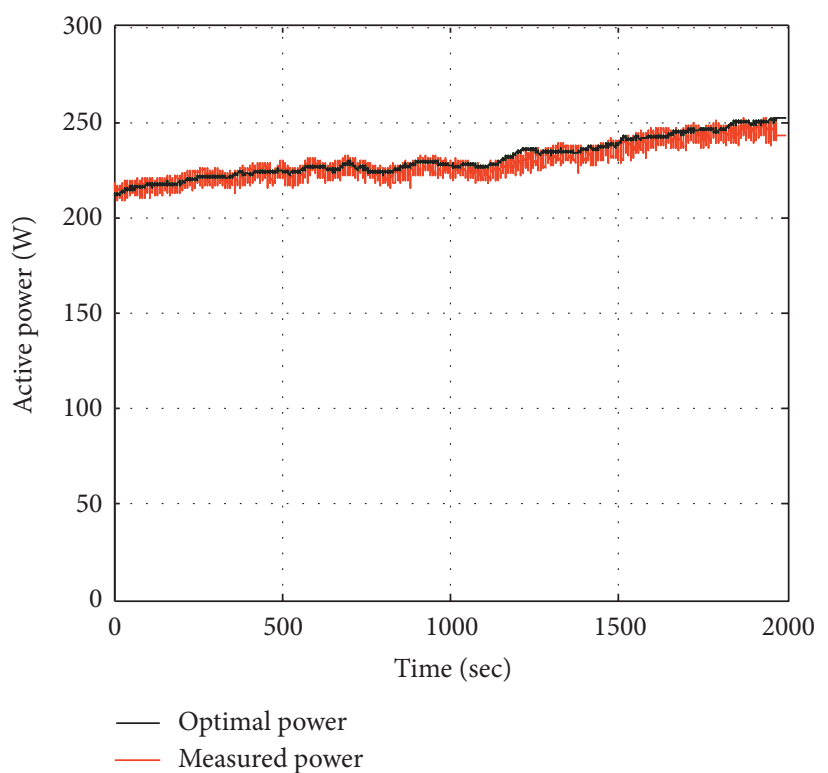

FIGURE 13: Evolution of real and reference powers of PVG.

Figures 14 and 15 represent the evolution of the efficiency and the real voltage of the generator. This efficiency clearly shows the efficiency of this current control with a value close to $100 \%$.

4.2. Hysteresis Voltage Controller Concept. Figure 16 presents the general structure of the hysteresis voltage controller system with its different blocks.

4.2.1. Design of Hysteresis Voltage Regulator. Two voltage control options have been designed: the first is internal (or open loop) control while the second is external (or closed loop). However the two voltage control options are identical in their basic designs with the current regulator described previously; the only difference is that, for the internal 


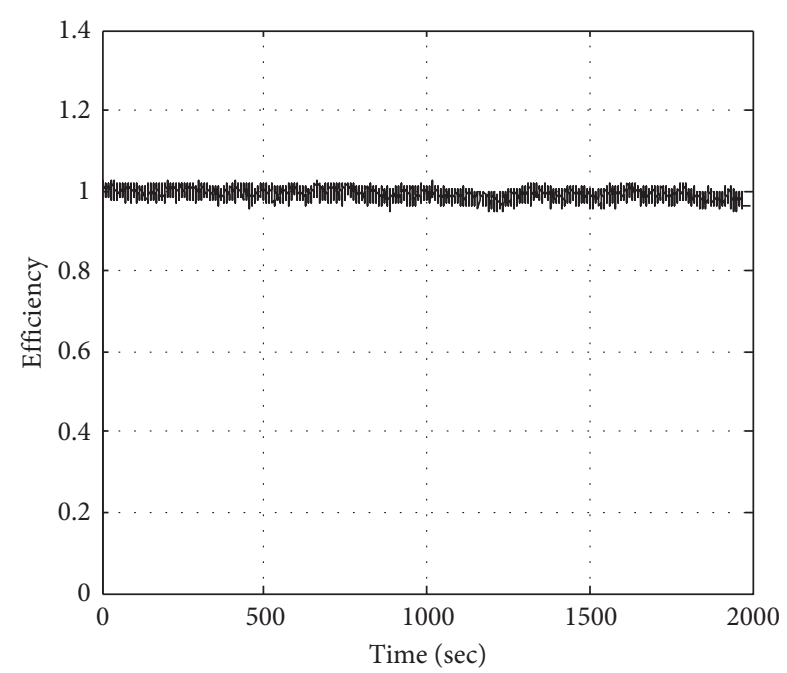

FIgURE 14: Efficiency of the $P v$ system.

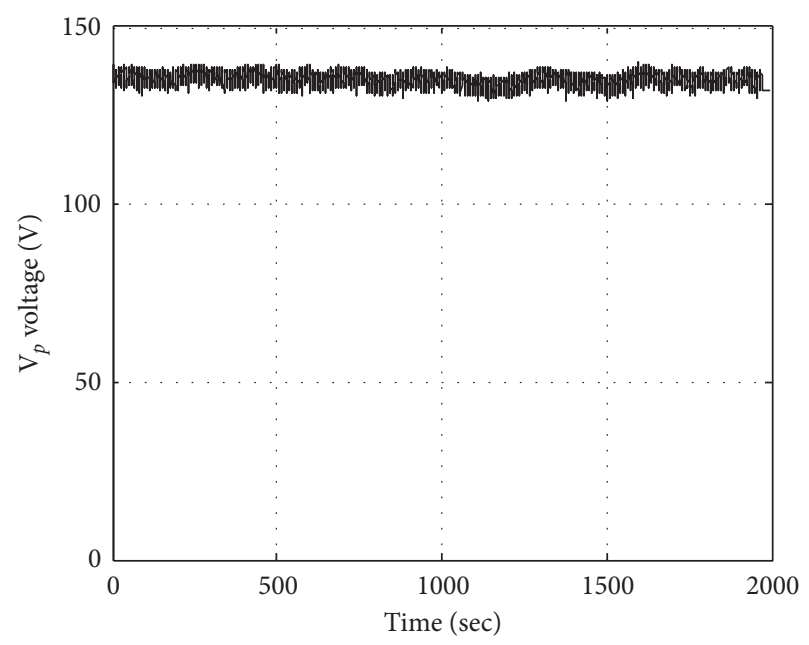

FIGURE 15: Evolution of real voltage of PVG.

control, we control the voltage across a capacitor of an RC circuit, filtering the control signal which drives the chopper. But, for the external control, the quantity to be controlled is measured by a suitable sensor external to the regulator.

The external regulator, operating in a closed loop, consists in controlling the voltage applied to the resistive load so that the latter supplies a DC voltage at a reference value. This regulator has the same structure as the current regulator described above, except that the input $v(t)$ is a voltage measured by a suitable sensor at the output of a rectifier bridge, connected in parallel with the load. The two types of voltage regulator are placed in the same box shown in Figure 17. The type of control (internal or external) is selected by a simple changeover switch.

4.2.2. Simulation of $P V$ System with Hysteresis Voltage Control. While using the same simulation parameters as the current command, and with real scenarios, we found these results which respectively show the evolution of solar radiation Figure 18 and temperature Figure 19.
Both actual and optimal voltages are shown in Figure 20. This result clearly proves that the voltage $V_{p v}$ always remains in the vicinity of $V_{\text {ref }}$ despite the change in climatic conditions. So, we can conclude about the profitability of this type of control.

As usual, both real and optimum powers are recorded. Always the $P_{p v}$ power is very close to its reference as shown in Figure 21.

From the ratio between the two powers (measured active power and optimal active power), we recorded the efficiency which always shows the good response of this type of command which is based on the control of voltages Figure 22.

4.3. Comparative Study. In this part, we will try to compare (more or less) the two approaches studied from a power point of view. Figures 23 and 24 clearly show the evolution of "DeltaP" which presents the power difference between two successive points. Then, with the scenarios used, the current control shows more efficiency in following the maximum power than the voltage control as shown in Table 2 .

The ease of implementing different methods has an important influence on the decision to select one MPPT technique among the others.

Therefore, these techniques are characterized by their ease of implantation. Although the operating point is close to the PPM, the major drawback of this type of method is sometimes the estimation of Icc and Vco.

4.4. Experimental Results. Figure 25 gives a global view of photovoltaic panels installed on the roof of the laboratory of the ERCO Research Unit at INSAT. This Solar System is composed of ten identical panels having the characteristics indicated in Table 1.

To validate the previously proposed models, we exploited these photovoltaic panels in connection with a load resistance.

Figure 26 shows the experimental test bench used to implement and study the proposed MPPT performances. This test bench consists essentially of a PV generator, an illuminance sensor, a temperature sensor, a voltage, and current sensors, all of which are designed and built within the ERCO-INSAT research unit, a push-pull converter, a buck converter, dSpace card DS1104 and control panel, and finally a variable resistive load of $400 \mathrm{~W}$ power. The variation of the load value is ensured by 7 -step switches.

4.5. Experimental Results of PV System with Hysteresis Current Control. For the experimental results, we used just five modules connected in parallel to supply the resistive load. That means in the STC conditions $\left(E=1000 \mathrm{~W} / \mathrm{m}^{2}\right.$ and $T=25^{\circ} \mathrm{C}$ ), we have $P_{m}=250 \mathrm{~W}, V_{m}=17.2 \mathrm{~V}$, and $I_{m}=5.7 \mathrm{~A}$.

Figures 27 and 28 show, respectively, the evolution of temperature and solar radiation. 


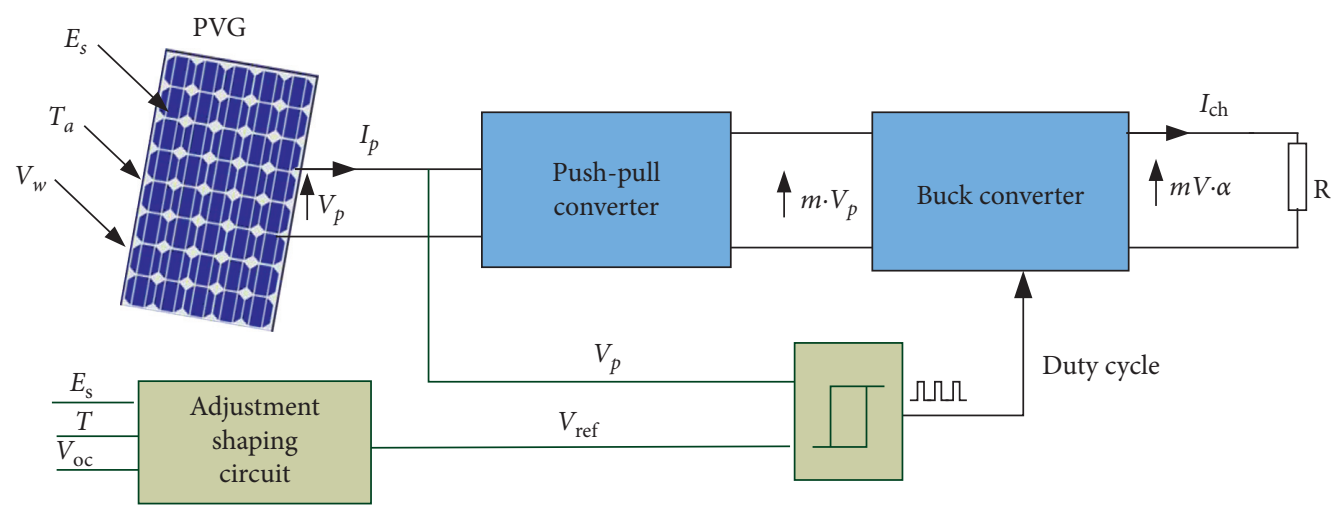

Figure 16: Circuit of the studied system.

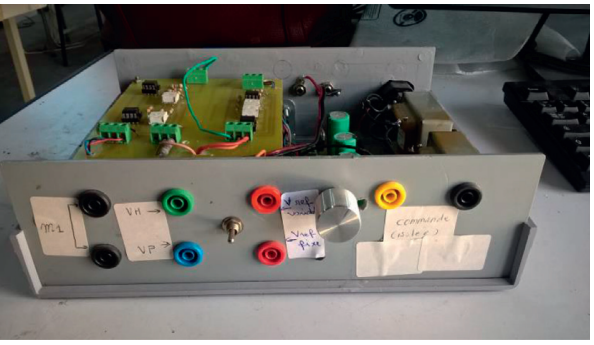

FIgURE 17: Overview of the card of hysteresis voltage controller.

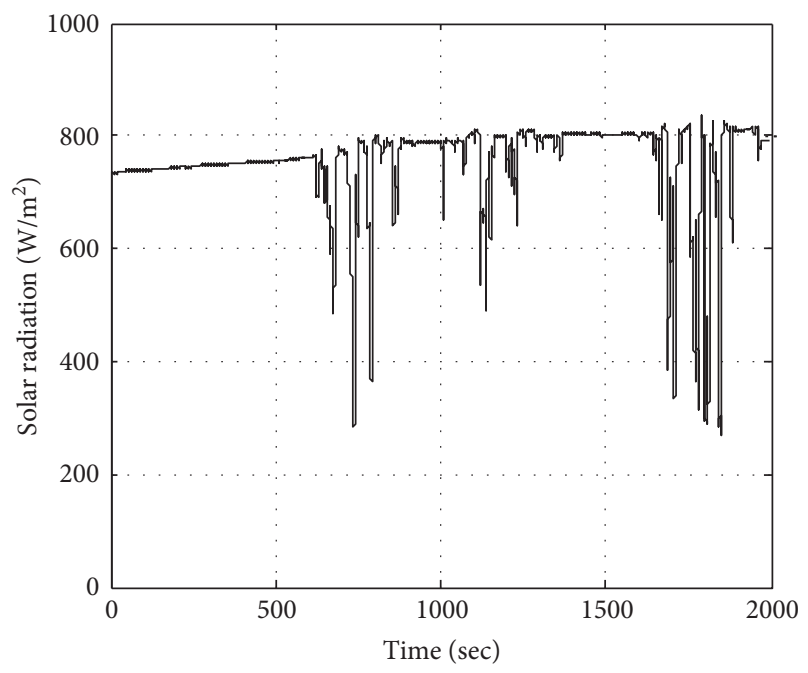

FIGURE 18: Evolution of solar radiation.

The behaviour of the voltage and power photovoltaic shows that the MPPT algorithm is robust despite the rapid changes in solar radiation and temperature.

Figures 29 and 30 , respectively, illustrate the evolution of photovoltaic power $P_{p v}$ and voltage $V_{p v}$.

Figures 31 and 32 give the change of the two real and reference currents and the variation of the operating point in the plane $P_{p v}-I_{p v}$.

The experimental results show that the proposed MPPT approach has a fast response under rapid solar irradiance variations.

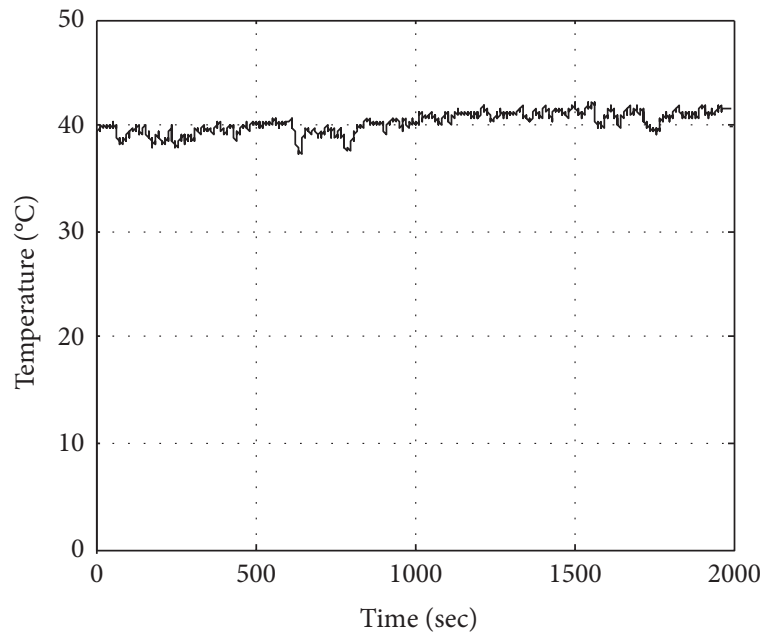

FIgURE 19: Evolution of temperature.

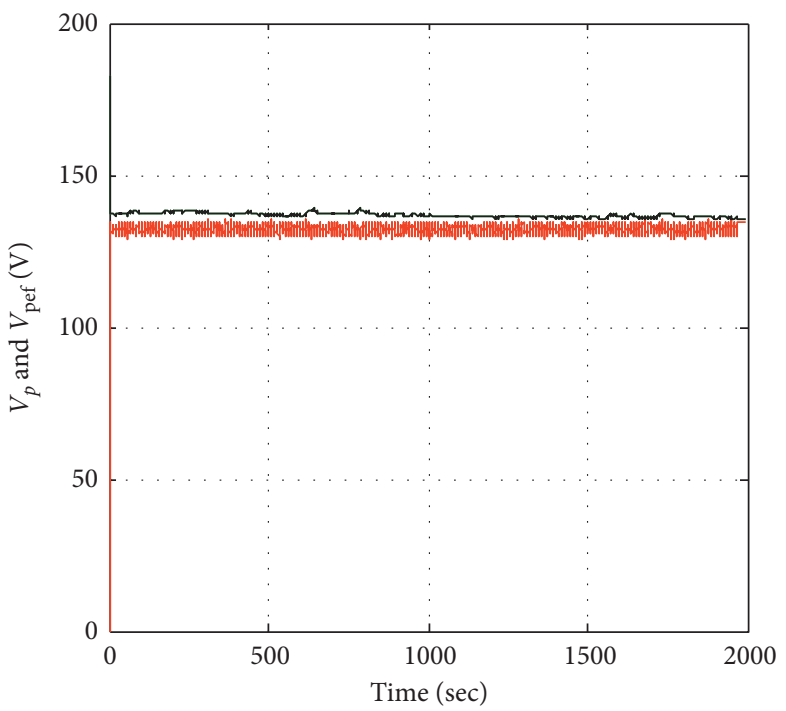

FIGURE 20: Evolution of real and optimal voltages of PVG.

4.6. Experimental Results of PV System with Hysteresis Voltage Control. With the same generator as the previous method, we also tried to implement this technique, the lighting and temperature scenarios are shown by Figures 33 and 34 . 


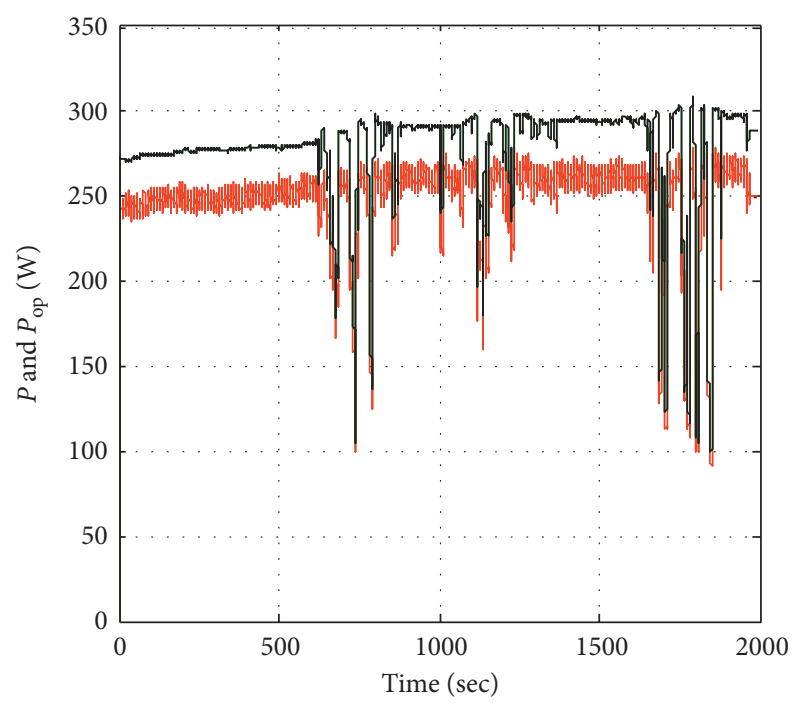

FIgURE 21: Evolution of real and reference powers of PVG.

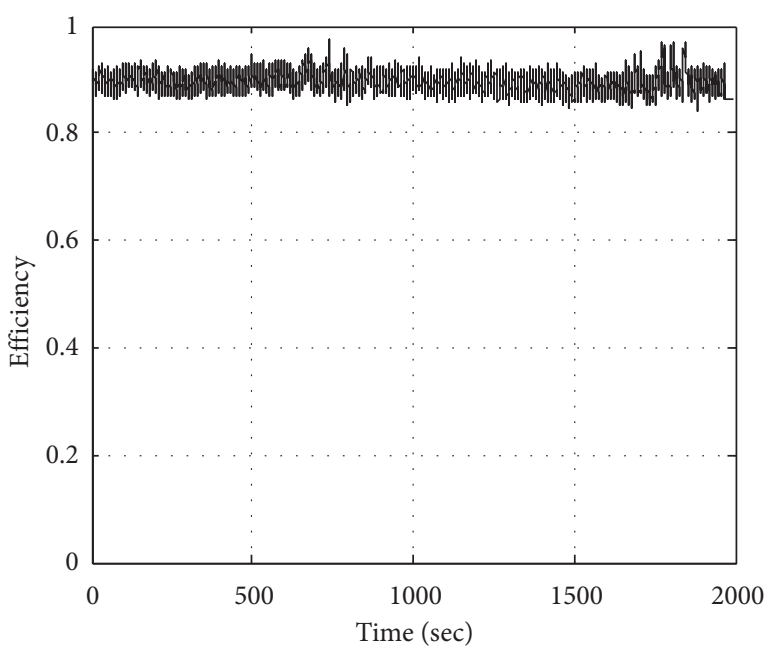

Figure 22: Efficiency of the $P v$ system.

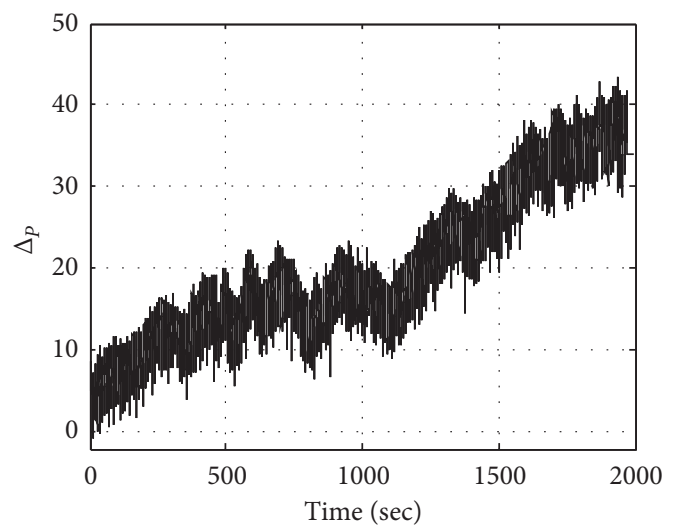

Figure 23: Evolution of "DeltaP" of current control.

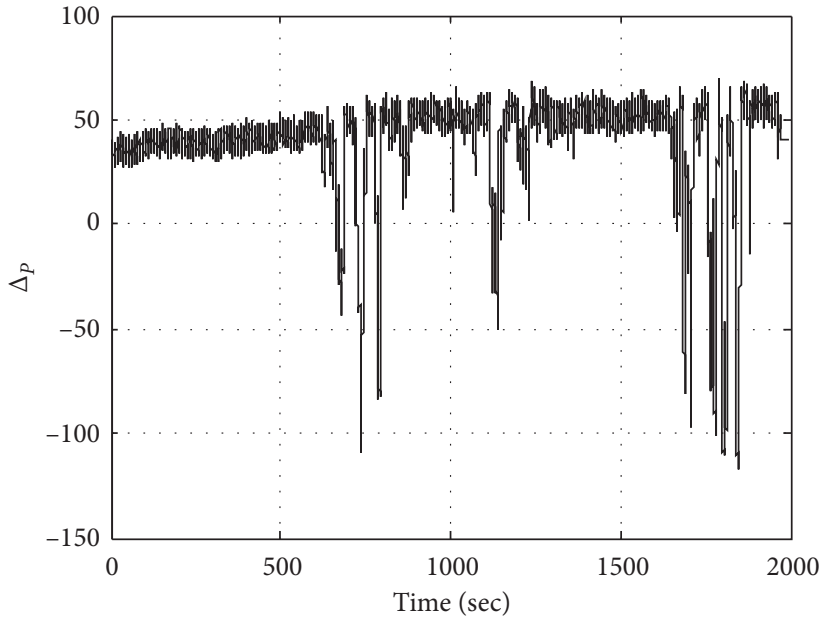

Figure 24: Evolution of "DeltaP" of voltage control.

TABle 2: Values of "DeltaP."

\begin{tabular}{lcc}
\hline DeltaP & $\min$ & $\max$ \\
\hline Hysteresis current control & 0 & 40 \\
Hysteresis voltage control & -110 & 60 \\
\hline
\end{tabular}

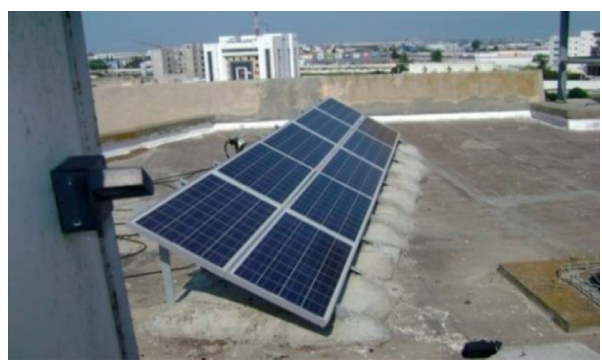

FIGURE 25: PV generator installed on ERCO-INSAT.

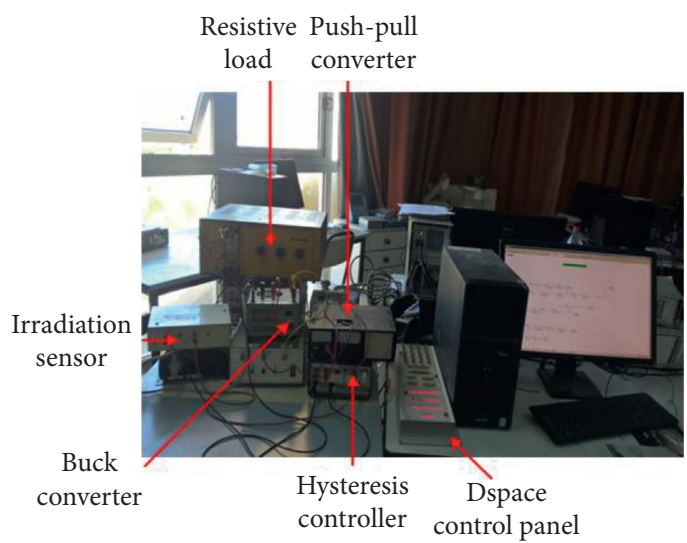

Figure 26: Configuration of the experimental set used.

Figures 35 and 36 , respectively, present the variation of real current as a function of time and especially the monitoring of the maximum voltage. 


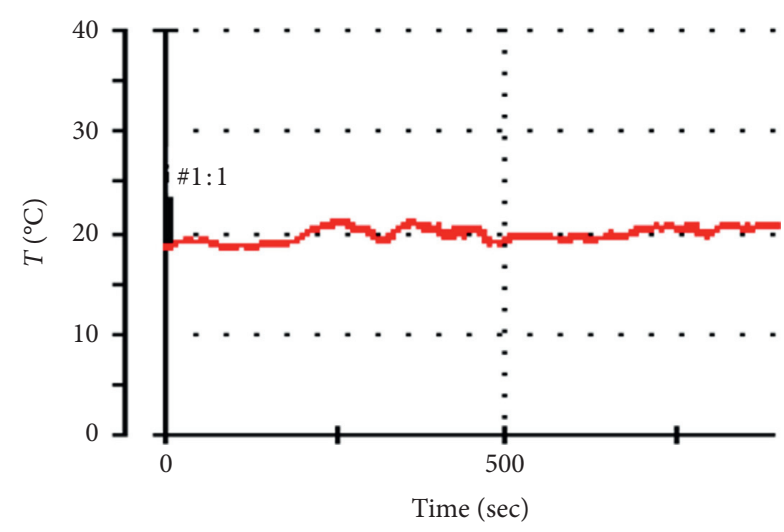

\#1:1 T (labels/T)

Figure 27: Evolution of temperature.

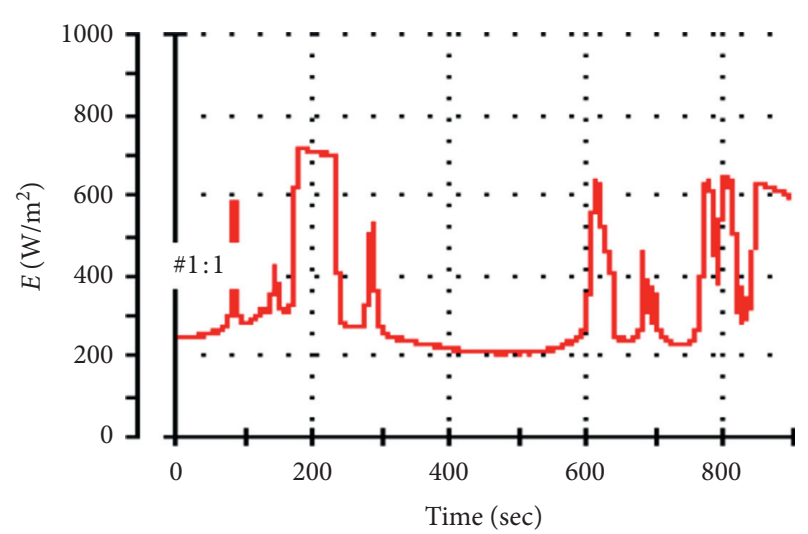

\#1:1 E (labels/E)

FIgURE 28: Evolution of solar radiation.

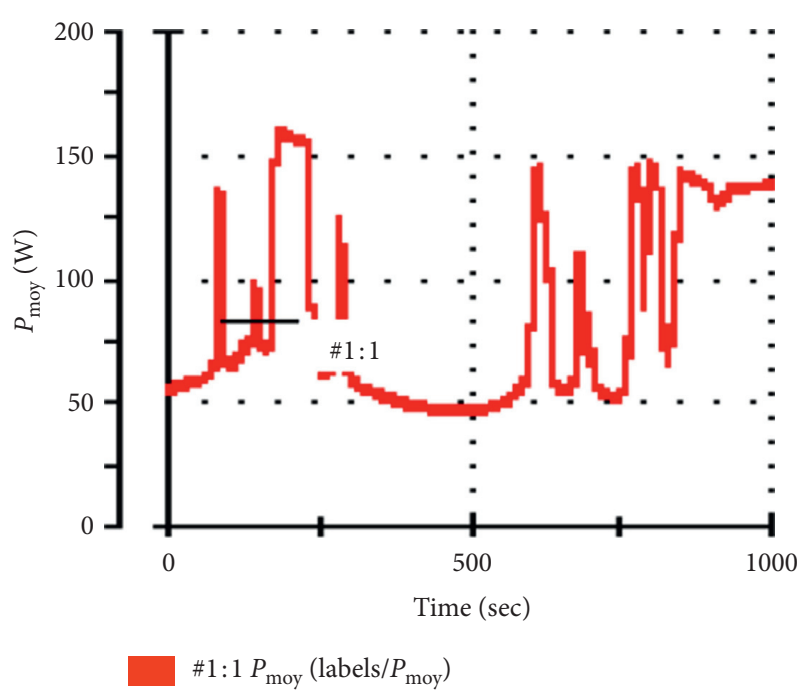

Figure 29: Evolution of photovoltaic power.

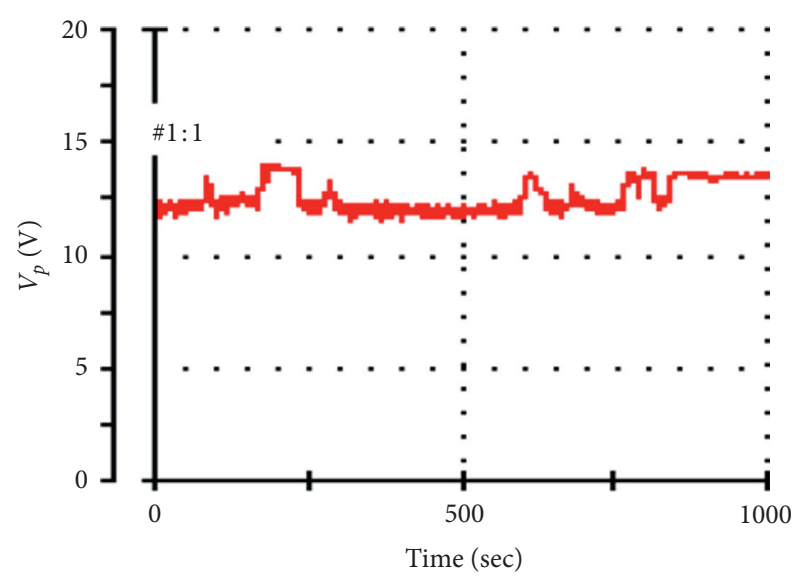

$\# 1: 1 V_{p}\left(\right.$ labels $\left./ V_{p}\right)$

FIgURE 30: Evolution of photovoltaic voltage.

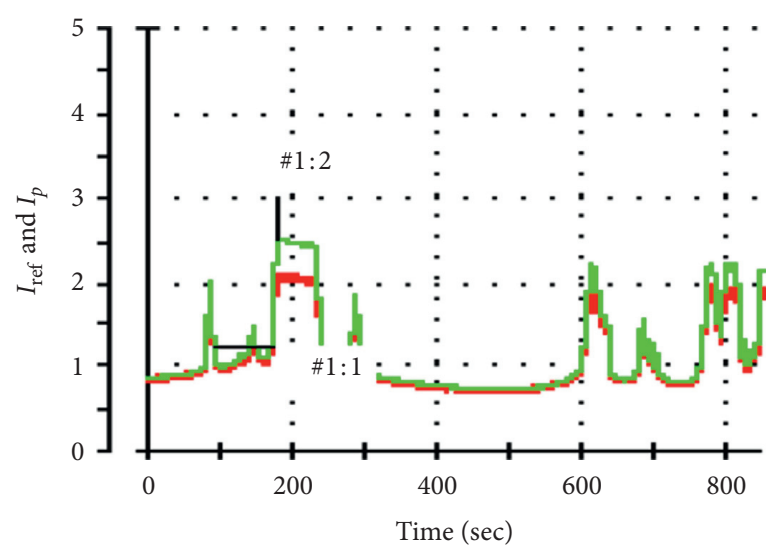

$\# 1: 1 I_{p}\left(\right.$ labels $\left./ I_{p}\right)$

\#1:2 $I_{\text {ref }}\left(\right.$ labels $\left./ I_{\text {ref }}\right)$

Figure 31: Evolution of $I_{p v}$ and $I_{\text {ref }}$.

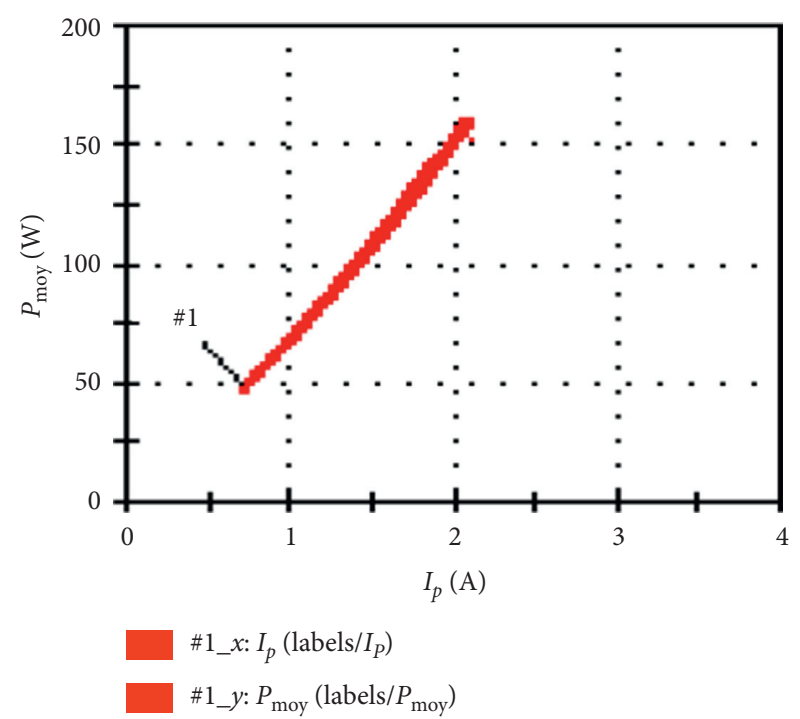

FIgURe 32: Evolution of operating point in $P_{p v}-I_{p v}$ plane. 


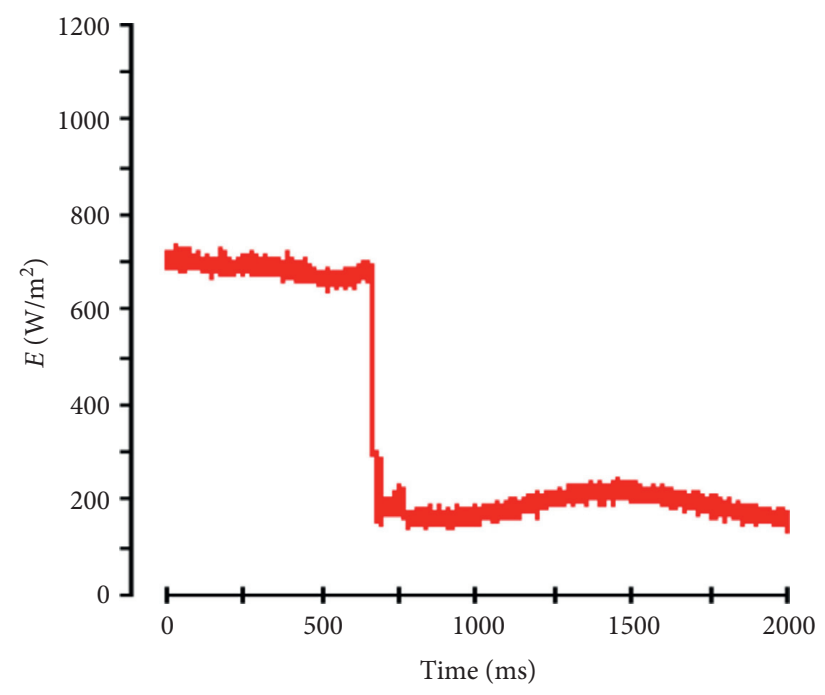

FIGURE 33: Evolution of solar radiation.

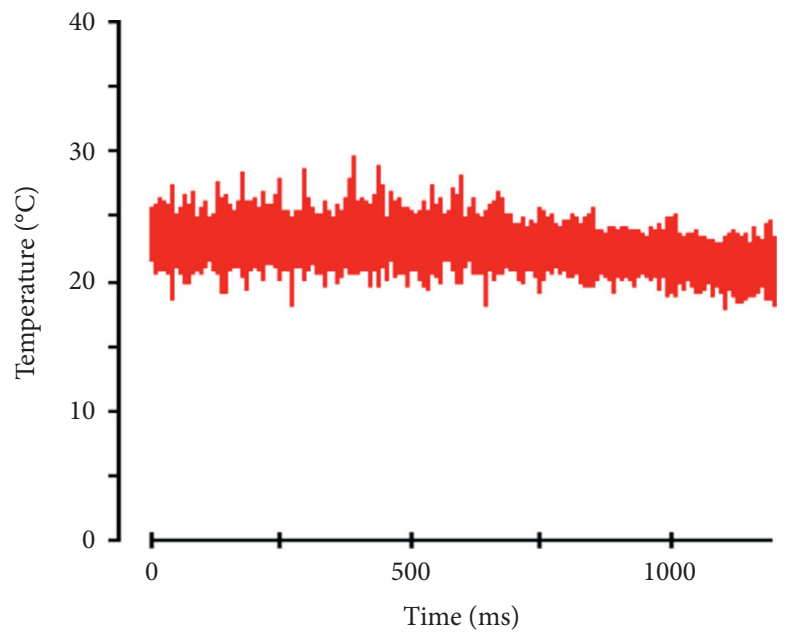

FIgURE 34: Evolution of temperature.

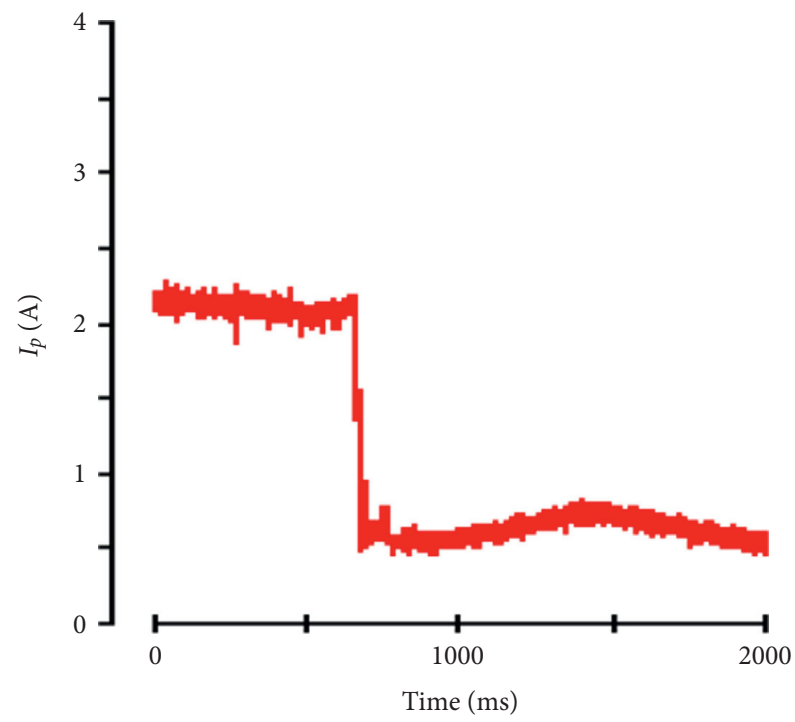

FIgURe 35: Evolution of real current of PVG. 


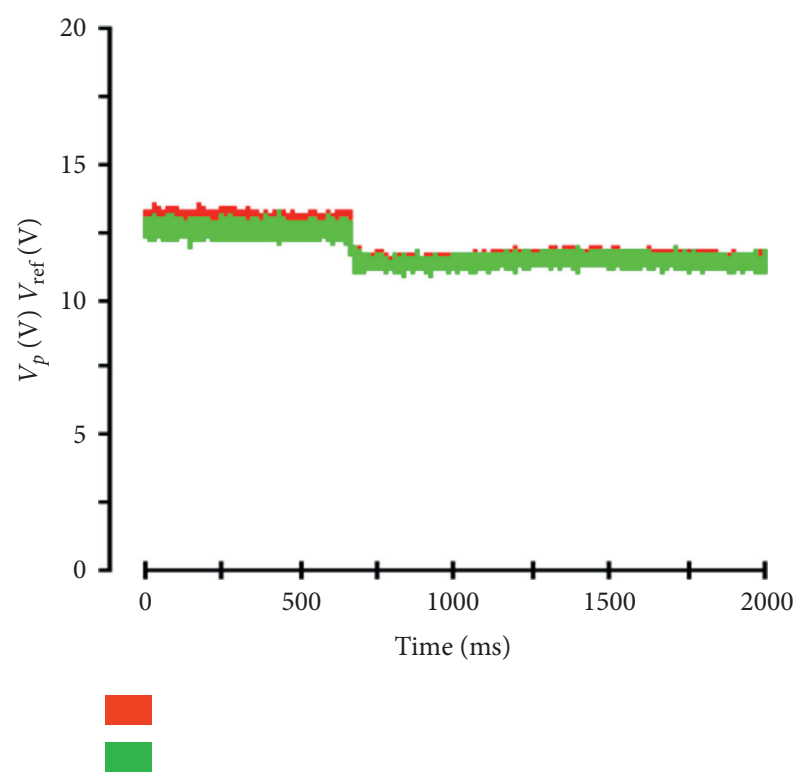

FIgURE 36: Evolution of optimal and real voltages.

\section{Conclusion}

In this work, the interest in inserting an adaptation stage between the source and the load was discussed. The structure of buck and push-pull choppers has been adopted. The principle of a hysteresis controller has been exposed, tested, and implemented. These results essentially make it possible to present the advantages of these control approaches which offer good tracking of MPP and above all a very good conformity between the real current and voltage of the PVG and the reference values.

The main objective of this research is to develop two MPPT controllers for a PV system in order to obtain maximum power with random scenarios of climatic factors. The simulation results as well as the experimental validation show a very great efficiency of the hysteresis regulators which has ensured essentially a very good control in current and voltage which causes the extraction of the optimum of power.

Finally, the experimental validation was presented to confirm the results found by simulation. The test bench is based on the use of the DS1104 card in order to implement the adopted control structures.

\section{Nomenclature}

$E_{s}: \quad$ Solar radiation $\left(\mathrm{W} / \mathrm{m}^{2}\right)$

$T_{j}$ : $\quad$ Temperature of diode junction $\left(\mathrm{K}^{\circ}\right)$

$\omega g$ : $\quad$ Energy gap of junction $(\mathrm{eV})$

$q$ : $\quad$ Electronic charge $\left(1.6 \cdot 10^{-13} \mathrm{C}\right)$

$\mathscr{K}_{B}: \quad$ Boltzmann's constant $\left(\mathrm{J} / \mathrm{K}^{\circ}\right)$

$\mathscr{K}_{I}: \quad$ Diode quality factor

$r_{s}: \quad$ Series resistor $(\Omega)$

$r_{s h}: \quad$ Shunt resistor $(\Omega)$

$i_{c c}: \quad$ Short-circuit current (A)

$i_{p h}: \quad$ current diode (A)

$i_{s}$ : $\quad$ Saturation current diode (A)
$T_{a}: \quad$ Ambient temperature $\left({ }^{\circ} \mathrm{C}\right)$

$v_{T}$ : Thermal voltage of the diode $(\mathrm{V})$

$v_{c o}: \quad$ Open-circuit voltage $(\mathrm{V})$

$V_{\omega}: \quad$ Wind speed

$m=20$ : Ratio of push-pull converter.

\section{Data Availability}

The parameters of the photovoltaic panel used to support the findings of this study are included within the article.

\section{Conflicts of Interest}

The authors declare that they have no conflicts of interest.

\section{References}

[1] R. Gammoudi, N. Rebei, and O. Hasnaoui, "STM microcontroller implementation of MPPT algorithms for standalone PV water pumping system," International Journal of Engineering and Technical Research (IJETR), vol. 3, no. 9, pp. 114-121, 2015.

[2] A. Hemza, H. Abdeslam, R. Chenni, and D. Narimene, "Photovoltaic system output simulation under various environmental conditions," in Proceedings of 2016 International Renewable and Sustainable Energy Conference IRSEC, pp. 722-726, Marrakech, Morocco, November 2016.

[3] S. Chander, A. Purohit, A. Sharma, S. P. Nehra, and M. S. Dhaka, "A study on photovoltaic parameters of monocrystalline silicon solar cell with cell temperature," Energy Reports, vol. 1, pp. 104-109, 2015.

[4] D. E. Carlson, G. Lin, and G. ganguly, "Temperature dependence of amorphous silicon solar cell pv parameters," in Proceedings of the 28th IEEE Photovoltaic Specialists Conference, p. 707, Anchorage, AK, USA, June 2000.

[5] R. Gammoudi, N. Rebei, and O. Hasnaoui, "Implementation MPPT approaches of PV system," International Journal of Renewable Energy, vol. 9, no. 2, pp. 21-30, 2014.

[6] D. Rekioua and E. Matagne, Optimization of Photovoltaic Power Systems: Modelization, Simulation and Control, Springer, Berlin, Germany, 2012, ISBN 978-1-4471-2348-4.

[7] B. Chitti Babu, R. Sudharshan Kaarthik, D. Nayan Kumar, R. Vigneshwaran, and R. Narayan Das, "Photovoltaic energy conversion system for water pumping applications-modeling and simulation," in Proceedings of the International Symposium on Photovoltaic Science and Technology, Kanpur, India, January 2010.

[8] K. H. Hussein, I. Muta, T. Hoshino, and M. Osakada, "Maximum photovoltaic power tracking: an algorithm for rapidly changing atmospheric conditions," IET ProceedingsGeneration Transmission and Distribution, vol. 142, no. 1, pp. 59-64, 1995.

[9] R. Gammoudi, N. Rebei, and O. Hasnaoui, "Study and implementation of current control MPPT approach for PV water pumping system," in Proceedings of the 9th Congrés international sur les energies renouvelables et l'environnement CERE'2015, Sousse, Tunisie, March 2015.

[10] R. Alik, A. Jusoh, and T. Sutikno, "A review on perturb and observe maximum power point tracking in photovoltaic system," Indonesian Journal of Electrical Engineering and Computer Science, vol. 13, no. 3, pp. 745-751, 2015.

[11] M. R. Gammoudi, Y. H. Brahmi, and J. O. Hasnaoui, "Comparative study of modified and conventional $\mathrm{P} \& \mathrm{O}$ 
method for PV system," in Proceedings of the International Conference on Innovative Trends in Energy, Dubrovnik, Croatia, October 2021.

[12] H. Brahmi and R. Dhifaoui, "Dynamic characteristics and improved MPPT control of PV generator," Frontiers in Energy, vol. 7, no. 3, pp. 342-350, 2013.

[13] K. K. Tse, B. M. H. Shu-Hung Chung, and S. Y. Ron Hui, "A comparative study of maximum-power-point trackers for photovoltaic panels using switching-frequency modulation scheme," IEEE Transactions on Industrial Electronics, vol. 51, no. 2, pp. 410-418, 2004.

[14] V. R. Kolluru, K. K. Mahapatra, and B. Subudhi, "Development and implementation of control algorithms for a photovoltaic system," in Proceedings of the 2013 Students Conference on Engineering and Systems, Karlsruhe, Germany, May 2013.

[15] R. Gammoudi, H. Brahmi, and O. Hasnaoui, "Principle of modified incremental conductance sliding mode MPPT control applied of photovoltaic system," in Proceedings of the 5th International Conference on Green Energy and Environmental Engineering, GEEE'2018, Sousse, Tunisia, April 2018.

[16] C. Li, Y. Chen, D. Zhou, J. Liu, and J. Zeng, "A high-performance adaptive incremental conductance MPPT algorithm for photovoltaic systems," Energies, vol. 9, no. 4, p. 288, 2016.

[17] R. Gammoudi, H. Brahmi, and O. Hasnaoui, "Developed and STM implementation of modified P\&O MPPT technique for a PV system over sun," European Power Electronics and Drives, vol. 29, 2019.

[18] S. A. Gorji, M. Ektesabi, and J. Zheng, "Isolated switchedboost push-pull DC-DC converter for step-up applications," Electronics Letters, vol. 53, no. 3, pp. 177-179, 2017.

[19] D. Maiti, N. Mondal, and S. K. Biswas, "Design procedure of a push pull current-fed DC-DC converter," in Proceedings of National Power Electronics Conference (NPEC), Roorkee, India, June 2010.

[20] A. Betka and A. Moussi, "Performance optimization of a photovoltaic induction motor pumping system," Renewable Energy, vol. 29, no. 14, pp. 2167-2181, 2004.

[21] R. Namba, Develop Ment of PSoC Microcontroller Based Solar Energy Storage System, pp. 718-721, Waseda University, Tokyo, Japan, 2011.

[22] O. Boukli-Hacene and C. Ali, "Robust regulation of the photovoltaic voltage using sliding mode control as part of a MPPT algorithm," International Journal of Computer Applications, vol. 78, no. 11, pp. 43-48, 2013.

[23] B. Abdelhakim, "Conception et implémentation d'une commande MPPT de haute performance pour une chaine de conversion photovoltaique autonome," Doctoral Thesis, University Ferhat Abbas, Setif, Algeria, 2015.

[24] A. S. Swathy and R. Archana, "Maximum power point tracking using modified incremental conductance for solar photovoltaic system," International Journal of Engineering and Innovative Technology (IJEIT), vol. 3, no. 2, pp. 333-337, 2013.

[25] A. Safari and S. Mekhilef, "Simulation and hardware implementation ofIncremental conductance MPPT with direct control method using cuk converter," IEEE Transactions on Industrial Electronics, vol. 58, no. 4, pp. 1154-1161, 2011.

[26] Y. Zhou, F. Liu, J. Yin, and S. Duan, "Study on realizing MPPT by improved incremental conductance method with variable step-size," in Proceedings Of The IEEE Conferences On Industrial Electronics And Applications, Singapore, June 2008.

[27] T. Radjai, L. Rahmani, S. Mekhilef, and J. P. Gaubert, "Implementation of a modified incremental conductance
MPPT algorithm with direct control based on a fuzzy duty cycle change estimator using dSPACE," Solar Energy, vol. 110, pp. 325-337, 2014.

[28] E. Koutroulis, K. Kalaitzakis, and C. Nicholas, "Development of a microcontroller-Based,Photovoltaic maximum power point tracking control system," IEEE Transactions on Industrial Electronics, vol. 16, no. 1, pp. 46-54, 2001.

[29] K. S. Tey and S. Mekhilef, "Modified incremental conductance algorithm for photovoltaic system under partial shading conditions and load variation," IEEE Transactions on Industrial Electronics, vol. 61, no. 10, pp. 5384-5392, 2014.

[30] K. S. Tey and S. Mekhilef, "Modified incremental conductance MPPT algorithm to mitigate inaccurate responses under fastchanging solar irradiation level," Solar Energy, vol. 101, no. 1, pp. 333-342, 2014.

[31] M. Ali Ozcelik and A. S. Yilmaz, "Modification of the incremental conductance algorithm in grid connected photovoltaic systems," Revue Roumaine des Sciences Techniques, Série Électrotechnique et Énergétique, vol. 61, no. 2, pp. 164168, 2016.

[32] D. Imen, Commande Des Systèmes Non Linéaires Par Mode Glissant D'ordre Supérieur, University of Constantine 1, Constantine, Algérie, 2013.

[33] Y. Levron and D. Shmilovitz, "Maximum power point tracking employing sliding mode control," IEEE Transactions on Circuits and Systems I: Regular Papers, vol. 60, no. 3, pp. 724-732, 2013.

[34] M. Veerachary, T. Senjyuand, and K. Uezato, "Feedforward maximum power point tracking of PV systems using fuzzy controller\|," IEEE Transactions On Aerospace and Electronic Systems, vol. 38, no. 3, pp. 969-981, 2002.

[35] N. S. D'Souza, L. A. C. Lopes, and X. Liu, "An intelligent maximum power point tracker using peak current control\|," in Proceedings of the IEEE Power Electronics Specialists Conference 2005, PESC'05, pp. 172-177, New York, NY, USA, February 2005.

[36] M. Veerachary and N. Yadaiah, "ANN based peak power tracking for PV supplied DC motors," Solar Energy, vol. 69, no. 4, pp. 343-350, 2000.

[37] T. Hiyama, "Identification of optimal operating point of PV modules using neural network for real time maximum power tracking control," IEEE Transactions on Energy Conversion, vol. 10, no. 2, pp. 360-367, 1995.

[38] T. Hiyama, "Evaluation of neural network based real time maximum power tracking control for PV system," IEEE Transactions on Energy Conversion, vol. 10, no. 3, pp. 543-548, 1995.

[39] T. Hiyama, "Neural network based estimation of maximum power generation from PV modules using environmental information," IEEE Transactions on Energy Conversion, vol. 12, no. 3, pp. 241-247, 1997.

[40] R. R. Colin and E. R. Jonathan, "Genetic algorithms-principles and perspectives," A Guide to GA Theory, Kluwer Academic Publishers, Dordrecht, Netherlands, 2002.

[41] S. Raja Mohamed, P. Aruna Jeyanthy, and D. Devaraj, "Hysteresis-based voltage and current control techniques for grid connected solar photovoltaic systems: comparative study," International Journal of Electrical and Computer Engineering (IJECE), vol. 8, no. 5, pp. 2671-2681, 2018.

[42] T. R. Premila and R. Krishna Kumar, "PR and hysteresis controlled PV fed cascaded boost ReBoost inverter systems," International Journal of Recent Technology and Engineering (IJRTE), vol. 8, no. 2S11, 2019. 
[43] R. latha, C. Bharatiraja, R. Palanisamy, and S. Dash, "Hysteresis current controller based transformerless split inductor-NPCMLI for grid connected PV-system," Procedia Engineering, vol. 64, 2013.

[44] A. W. Cristri and R. F. Iskandar, "Analysis and design of dynamic buck converter with change in value of load impedance," Procedia Engineering, vol. 170, pp. 398-403, 2017.

[45] N. H. Baharudin, T. M. N. T. Mansur, F. A. Hamid, R. Ali, and M. I. Misrun, "Performance analysis of DC-DC buck converter for renewable energy application," Journal of Physics Conference Series, vol. 1019, 2018.

[46] M. A. E. Andersen, "Hysteresis controller with constant switching frequency," IEEE Transactions on Consumer Electronics, vol. 51, no. 2, pp. 688-693, 2005.

[47] T. Nguyen-Van, R. Abe, and K. Tanaka, "A digital hysteresis current control for half-bridge inverters with constrained switching frequency," Energies, vol. 10, 2017.

[48] A. Sellami, K. Kandoussi, R. El Otmani, M. Eljouad, O. Mesbahi, and A. \&Hajjaji, "A novel auto-scaling MPPT algorithm based on perturb and observe method for photovoltaic modules under partial shading conditions," Applied Solar Energy, vol. 54, no. 3, pp. 149-158.

[49] H. Taheri, Z. Salam, and K. Ishaque, "A novel Maximum Power Point Tracking control of photovoltaic system under partial and rapidly fluctuating shadow conditions using differential evolution," in Proceedings of the IEEE Symposium on Industrial Electronics and Applications ISIEA, pp. 82-87, Penang, Malaysia, October 2010.

[50] I. Colak and E. Kabalci, Control Methods Applied in Renewable Energy, Use, Operation and Maintenance of Renewable Energy Systems, Springer, Berlin, Germany, pp. 205-246, 2014.

[51] G. Azevedo, M. Cavalcanti, K. Oliveira, F. Neves, and Z. Lins, "Comparative evaluation of maximum power point tracking methods for photovoltaic systems," Journal of Solar Energy Engineering, vol. 131, no. 3, 2009.

[52] S. Zaamta* and A. Dib, "Réalisation d'un régulateur solaire à base de microcontrôleur pour le contrôle de l'état de charge et la protection des accumulateurs," Revue des Energies Renouvelables, vol. 12, pp. 137-147, 2009.

[53] S. K. Yadav and U. Bajpai, "Performance evaluation of a rooftop solar photovoltaic power plant in northern India," Energy for Sustainable Development, vol. 43, pp. 130-138, 2018. 